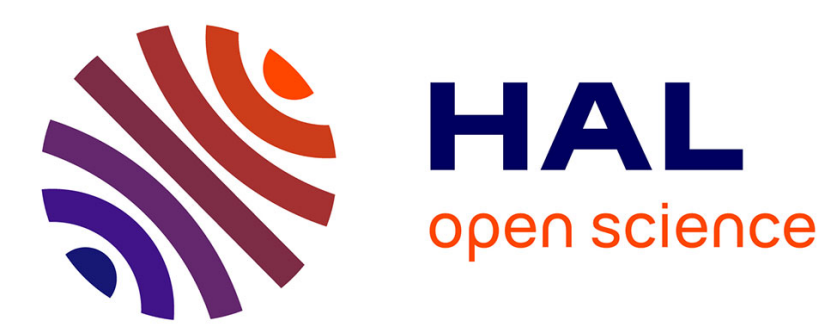

\title{
Avoidance of low doses of naphthalene by Collembola
}

\author{
Laetitia Boitaud, Sandrine Salmon, Céline Bourlette, Jean-François Ponge
}

\section{To cite this version:}

Laetitia Boitaud, Sandrine Salmon, Céline Bourlette, Jean-François Ponge. Avoidance of low doses of naphthalene by Collembola. Environmental Pollution, 2006, 139 (3), pp.451-454. 10.1016/j.envpol.2005.06.013 . hal-00363742

\section{HAL Id: hal-00363742 \\ https://hal.science/hal-00363742}

Submitted on 25 Feb 2009

HAL is a multi-disciplinary open access archive for the deposit and dissemination of scientific research documents, whether they are published or not. The documents may come from teaching and research institutions in France or abroad, or from public or private research centers.
L'archive ouverte pluridisciplinaire HAL, est destinée au dépôt et à la diffusion de documents scientifiques de niveau recherche, publiés ou non, émanant des établissements d'enseignement et de recherche français ou étrangers, des laboratoires publics ou privés. 
1 Type of contribution: Short communication

3 Avoidance of low doses of naphthalene by Collembola

4

5 Laetitia Boitaud, Sandrine Salmon, Celine Bourlette, Jean-François Ponge

6

Museum National d'Histoire Naturelle, CNRS UMR 5176, 4 avenue du Petit-Chateau, 91800 Brunoy, France

10 Corresponding author: J.F. Ponge, tel. +33-1-60479213, fax +33-1-60465009, e-mail:

11 jean-francois.ponge@wanadoo.fr

Capsule

$\mathrm{PAH}$ avoidance by soil springtails is species-specific and differs among populations of the same species

\section{Abstract}

The introduction of behavioural aspects of soil animals in ecological risk assessment would allow us to better assess soil quality, all the more if a range of animal populations are considered. We compared the avoidance behaviour of several strains of springtails (Arthropoda: Collembola) obtained from different soils. Naphthalene, a polycyclic aromatic hydrocarbon $(\mathrm{PAH})$ widely represented in soils polluted with hydrocarbons, was tested in aqueous solutions on nine springtail species issuing from four sites. Fine quartz sand saturated with an aqueous solution of naphthalene was avoided by most of the tested species, avoidance being however detected down to a concentration of $0.030 \mathrm{mg} \cdot \mathrm{L}^{-1}$. Folsomia candida (Isotomidae) was 
1 shown to be relatively tolerant to pollutants compared to other Collembola such as

2 Mesaphorura macrochaeta, M. yosii (Onychiuridae), Parisotoma notabilis (Isotomidae)

3 and Arrhopalites caecus (Arrhopalitidae). Differences between strains could not be

4 explained by properties of the original soils.

5

6 Key-words: Soil pollution; Collembola; Behaviour; Avoidance; Polycyclic Aromatic 7 Hydrocarbon (PAH)

8

\section{Introduction}

Polycyclic aromatic hydrocarbons (PAHs) are important compounds to be considered in environmental risk assessment (Riser-Roberts, 1998). Naphthalene, one of the smallest (in molecular size) and most common PAHs, is a neurotoxicant (Ritchie et al., 2001) and its carcinogenic effects are now fully recognized (Preuss et al., 2003). This pollutant has been used for decades in homes for deterring insects from clothing and to reduce densities of microarthopods in soils (Best et al., 1978).

Although still not fully recognized in ecological risk assessment, the avoidance of contaminants by soil animals has proven to be of ecological value at the micro-site level, by allowing sensitive species to move away from the pollution source (Tranvik and Eijsackers, 1989; Filser and Hölscher, 1997). Recent studies in ecotoxicology showed that avoidance tests using Collembola compare well in their outcome with tests of toxicity (Greenslade and Vaughan, 2003; da Luz et al., 2004).

We may wonder whether naphthalene, known to affect arthropod populations at high concentration (Best et al., 1978; Sverdrup et al., 2002), can be perceived and avoided at low doses, whether avoidance depends on the species and whether several populations of the same species avoid it to the same extent. 


\section{Materials and methods}

Different species collected from several sites in France were compared (Table

5 1). Soil from four sites was used for starting cultures. NS Brunoy was a neutral soil ( $\mathrm{pH}$

6 7.5) in an oak/hornbeam woodlot at Brunoy (lle-de-France). AS Brunoy was an acid

7 soil ( $\mathrm{pH} 4.5)$ in an oak/pine woodland at Brunoy. NS Pechelbronn was a neutral soil

$8(\mathrm{pH} 7)$ in an abandoned oil refinery at Pechelbronn (Alsace). AS Pfaffenbronn was an

9 acid soil ( $\mathrm{pH} 4.5)$ in an oak/beech woodland at Pfaffenbronn (Alsace). contact with any kind of pollutant. They stemmed from batch cultures performed from 1 to 3 years (according to species) on a standard substrate made of fine quartz sand moistened with tap water, powdered cow dung being added ad libitum. The test specimens were selected among fully developed (adult) animals from the same rearing box.

Avoidance experiments were performed in sterile polystyrene Petri dishes. The diameter of the dish was $35 \mathrm{~mm}$ (Mesaphorura macrochaeta, M. florae, M. yosii, Proisotoma minima), $52 \mathrm{~mm}$ (Folsomia candida, Isotomiella minor, Parisotoma notabilis) or $85 \mathrm{~mm}$ (Arrhopalites caecus, Heteromurus nitidus), depending on the size and activity of the species. Previous observations showed that tiny, short-legged springtails such as Mesaphorura spp. could not perform a choice within the duration of the experiment if they were not allowed to explore the whole dish in a first step. Conversely, bigger, very motile species such as Heteromurus nitidus were unable to make a choice if they lacked space for their movements. Two half-disks of glass fiber paper were moistened with deionised water then deposited at the the bottom of the Petri dish. The entire surface of each half-disk was covered with a thin layer $(1 \mathrm{~mm})$ of 
1 Fontainebleau sand saturated with different concentrations of the test solution (test half

2 disk) or deionised water (control half disk). The two half-disks were separated by a 2

$3 \mathrm{~mm}$ space, at the centre of which one naive specimen was deposited. The position of

4 the animal was recorded every 20 minutes for 100 minutes. This time interval was

5 selected on the base of similar experiments where the position of animals was

6 recorded every 10' (Salmon and Ponge, 2001). During the first 20' the animals

7 wandered continuously, then when a difference between both sides of the Petri dish

8 was perceived, most of them shifted to one or the other side. Twenty replicates were

9 used for each treatment, in two successive batches of ten. During the experiment, Petri

10 dishes were placed under a fluorescent illuminator in a temperature-controlled chamber

11 at $20^{\circ} \mathrm{C}$. Care was taken that the animals were not disturbed during observations, done

12 by transparency through the cover lid. Blank experiments checked for the absence of

13 effects of any light gradient which could bias the results (Salmon and Ponge, 1998).

14 For each of the four concentrations of naphthalene, differences between test and

15 control sides of Petri dishes were tested by paired $t$ test after check for the normal

16 distribution of count data (Sokal and Rohlf, 1995). Statistical tests were done on the

17 number of times (from 0 to 5 ) an animal was counted on each side of the Petri dish.

18 Results are presented as mean percent presence of animals on the test side (total of

$195 \times 20$ counts divided by 100$)$.

The test pollutant was naphthalene $\left(\mathrm{C}_{10} \mathrm{H}_{8}\right)$. Its water solubility is $30 \mathrm{mg} \cdot \mathrm{L}^{-1}$ at $20^{\circ} \mathrm{C}$ (Verschueren, 2001). A new solution of naphthalene was prepared before each test run to prevent the appearance of degradation products. Before use, the solution was put on a magnetic blender for one night at $20^{\circ} \mathrm{C}$. Three dilution rates $(0.3,0.03$, $\left.0.003 \mathrm{mg} \cdot \mathrm{L}^{-1}\right)$ and the mother solution $\left(30 \mathrm{mg} \cdot \mathrm{L}^{-1}\right)$ were tested.

\section{Results and discussion}


Table 2 shows the results of all behavioural tests. For $H$. nitidus, only the saturated concentration ( $\left.30 \mathrm{mg} \cdot \mathrm{L}^{-1}\right)$ was tested because of a lack of individuals in the rearing box. At the highest concentration of naphthalene (30 mg. $\left.\mathrm{L}^{-1}\right)$, specimens from all but three strains avoided the polluted side (mean percent presence $\leq 32 \%$ on the test side) but no mortality was found. Avoidance was still displayed by most strains at $0.3 \mathrm{mg} \cdot \mathrm{L}^{-1}$. Naphthalene was not avoided by $F$. candida (AS Pfaffenbronn), H. nitidus (NS Pechelbronn) and $P$. minima (AS Brunoy). Only $M$. yosii (AS Brunoy) and $P$. notabilis (NS Pechelbronn) avoided the naphthalene at $0.03 \mathrm{mg} \cdot \mathrm{L}^{-1}$. No species was sensitive at $0.003 \mathrm{mg} \cdot \mathrm{L}^{-1}$.

The absence of mortality within the duration of the experiment can be explained by the low concentration of the contaminant in aqueous solution, even when saturated (30 mg. $\mathrm{L}^{-1}$ ). One-month test cultures on the same substrate (pure fine quartz sand moistened with naphthalene solution, powdered cow dung added ad libitum) did not show any mortality of the introduced specimens, nor any definite trend of cessation of reproduction. Other studies showing the toxicity of naphthalene to soil Collembola used naphthalene as a powder (Best et al., 1978) or diluted in lipophilic solvents (Sverdrup et al., 2002), which added a vapour phase in the soil atmosphere. In our experiment, the odour of naphthalene was nil after the introduction of fine quartz sand. Previous assays without the addition of sand revealed a definite odour at the highest concentration, which did not allow the animals to perceive a difference between both sides of petri dishes. The presence of highly diffusible olfactory compounds should be considered as a severe limitation to the use of Petri dishes for testing avoidance, olfactometers, being recommended, although they are unfortunately not commercially available (Bengtsson et al., 1988).

The avoidance test discriminated between species and strains and no attraction was shown even at the lowest concentration. Most species avoided naphthalene at the 
1 highest concentration (30 mg. $\mathrm{L}^{-1}$ ) but still avoided it at $0.3 \mathrm{mg} \cdot \mathrm{L}^{-1}$. Only three species

2 were not sensitive at all to the tested $\mathrm{PAH}$, including $F$. candida. This species does not seem to be representative of the Isotomidae family, if not of the Collembola group, despite its standard use in ecotoxicology (ISO 11267). Mesaphorura macrochaeta, Mesaphorura yosii, Parisotoma notabilis and Arrhopalites caecus seem to be more sensitive indicators of soil toxicity.

(1)

Differences in the sensitivity of collembola to the studied PAH cannot be explained by ecological requirements of the species. Soil acidity (Senart, Pfaffenbronn) and PAH pollution (Pechelbronn) did not seem to select for more tolerant species and different strains of the same species did not avoid naphthalene at the same concentration threshold (Table 2). To the present state of our studies, acidophilic collembola do not seem to be more resistant to pollution by PAHs or heavy metals. Garnier and Ponge (2004) showed that despite similarities between the chemical environment of acid soils and that of metal-polluted soils, differences in $\mathrm{pH}$ and microbial communities prevented acid-tolerant populations from surviving and reproducing when introduced in a polluted site. In the present experiments, we demonstrated that, when placed in the same environmental conditions (for culture and experiment), acid-tolerant animals were not less sensitive to naphthalene than acidintolerant species. Two hypotheses can be proposed, i) an acclimatization time is required to reveal the tolerance of a given population, ii) populations which withstand low pHs and associated chemicals such as heavy metals, terpenes and phenolics are not necessarily tolerant to every contaminant.

Naphthalene is the commonest agent of soil and water pollution by hydrocarbons (Riser-Roberts, 1998; Preuss et al., 2003). Among PAHs, its higher solubility in water and higher diffusibility in the air make it mostly responsible for the immediate sensitivity of organisms to hydrocarbons (Ritchie et al., 2001; Sverdrup et 
1 al., 2002). Measuring the avoidance of naphthalene by soil animals can thus be

2 considered as a relevant tool to assess the immediate sensitivity of these organisms to

3 hydrocarbon pollution.

4

5 Acknowledgements

6

The present study has been undertaken with a financial support from the

Agence de l'Environnement et de la Maitrise de l'Énergie (ADEME), which is greatly acknowledged.

References

Bengtsson, G., Erlandsson, A., Rundgren, S., 1988. Fungal odour attracts soil Collembola. Soil Biology and Biochemistry 20, 25-30.

Best, G.R., Nabholz, J.V., Ojasti, J., Crossley, D.A. Jr, 1978. Response of microarthropod populations to naphthalene in three contrasting habitats. Pedobiologia 18, 189-201.

Filser, J., Hölscher, G., 1997. Experimental studies on the reactions of Collembola to copper contamination. Pedobiologia 41, 173-178.

Garnier, S., Ponge, J.F., 2004. Acid-tolerant Collembola cannot colonize metal-polluted soils at neutral pH. Applied Soil Ecology 26, 201-208.

Greenslade, P., Vaughan, G.T., 2003. A comparison of Collembola species for toxicity testing of Australian soils. Pedobiologia 47, 171-179. 
1 ISO 11267, 1999. Soil quality. Inhibition of reproduction of Collembola (Folsomia candida). International Standards Organization, Geneva, Switzerland.

3

da Luz, T.N., Ribeiro, R., Sousa, J.P., 2004. Avoidance tests with Collembola and earthworms as early screening tools for site-specific assessment of polluted soils. Environmental Toxicology and Chemistry 23, 2188-2193.

Preuss, R., Angerer, J., Drexler, H., 2003. Naphthalene. An environmental and occupational toxicant. International Archives of Occupational and Environmental Health 76, 556-576.

Riser-Roberts, E., 1998. Remediation of petroleum contaminated soils. Lewis, Boca Raton, Florida.

Ritchie, G.D., Still, K.R., Alexander, W.K., Nordholm, A.F., Wilson, C.L., Rossi III, J., Mattie, D.R., 2001. A review of the neurotoxicity risk of selected hydrocarbon fuels. Journal of Toxicology and Environmental Health, Part B, Reviews 4, 223312.

Salmon, S., Ponge, J.F., 1998. Responses to light in a soil-dwelling springtail. European Journal of Soil Biology 34, 199-201.

Salmon, S., Ponge, J.F., 2001. Earthworm excreta attract soil springtails: laboratory experiments on Heteromurus nitidus (Collembola: Enromobryidae). Soil Biology and Biochemistry 33, 1959-1969.

Sokal, R.R., Rohlf, F.J., 1995. Biometry. The Principles and Practice of Statistics in Biological Research. Freeman, New York, NY. 
2 Sverdrup, L.E., Nielsen, T., Krogh, P.H., 2002. Soil ecotoxicity of polycyclic aromatic 3 hydrocarbons in relation to soil sorption, lipophilicity, and water solubility. Environmental Science and Technology 36, 2429-2435.

5

6 Tranvik, L., Eijsackers, H., 1989. On the advantage of Folsomia fimetarioides over 7 Isotomiella minor (Collembola) in a metal polluted soil. Oecologia 80, 195-200.

8

9 Verschueren, K., 2001. Handbook of Environmental Data on Organic Chemicals. Wiley, 10 New York, NY. 
1 Table 1. List of collembolan species used in eco-ethological tests, and their origin and

2 taxonomic affiliation. NS = neutral soil $\left(\mathrm{pH}_{\text {water }} 7\right.$ or 7.5$), \mathrm{AS}=$ acid soil $\left(\mathrm{pH}_{\text {water }} 4.5\right)$

3

\begin{tabular}{|c|c|c|c|c|c|}
\hline Species & Family & Acidity & Humus form & Origin & Code \\
\hline Arrhopalites caecus & Arrhopalitidae & Neutral & Mull & Brunoy & NS Brunoy \\
\hline Folsomia candida & Isotomidae & Acid & Moder & Pfaffenbronn & AS Pfaffenbronn \\
\hline Isotomiella minor & Isotomidae & Acid & Moder & Brunoy & AS Brunoy \\
\hline Isotomiella minor & Isotomidae & Acid & Moder & Pfaffenbronn & AS Pfaffenbronn \\
\hline Mesaphorura florae & Onychiuridae & Neutral & Mull & Pechelbronn & NS Pechelbronn \\
\hline Mesaphorura macrochaeta & Onychiuridae & Acid & Moder & Pfaffenbronn & AS Pfaffenbronn \\
\hline Mesaphorura yosii & Onychiuridae & Acid & Moder & Brunoy & AS Brunoy \\
\hline Mesaphorura yosii & Onychiuridae & Acid & Moder & Pfaffenbronn & AS Pfaffenbronn \\
\hline Parisotoma notabilis & Isotomidae & Neutral & Mull & Pechelbronn & NS Pechelbronn \\
\hline Parisotoma nitabilis & Isotomidae & Acid & Moder & Pfaffenbronn & AS Pfaffenbronn \\
\hline Proisotoma minima & Isotomidae & Acid & Moder & Brunoy & AS Brunoy \\
\hline Proisotoma minima & Isotomidae & Acid & Moder & Pfaffenbronn & AS Pfaffenbronn \\
\hline
\end{tabular}

4 
1 Table 2. Avoidance tests. Mean ( \pm standard error) percent presence of collembola on 2 test side of Petri dishes ( 5 counts at 20 minute intervals, 20 replicates) at 4 dilution 3 rates of the naphthalene solution. Differences between control and test side were 4 tested by t test. Significant departure from no effect values (50\% presence on test side) 5 is indicated in bold underlined type $(P<0.05)$.

6

\begin{tabular}{llllll}
\hline Species & Strain origin & $\mathbf{0 . 0 0 3} \mathbf{~ m g . \mathrm { L } ^ { - 1 }}$ & $\mathbf{0 . 0 3} \mathbf{~ m g . \mathrm { L } ^ { - 1 }}$ & $\mathbf{0 . 3} \mathbf{~ m g . \mathrm { L } ^ { - 1 }}$ & $\mathbf{3 0 ~ \mathbf { ~ g } . \mathrm { L } ^ { - 1 }}$ \\
\hline H. nitidus & NS Pechelbronn & & & & $48.00 \pm 10.60$ \\
F. candida & AS Pfaffenbronn & $49.00 \pm 8.64$ & $40.00 \pm 7.68$ & $44.00 \pm 8.16$ & $52.00 \pm 7.73$ \\
I. minor & AS Pfaffenbronn & $42.00 \pm 8.07$ & $44.00 \pm 9.47$ & $\underline{\mathbf{3 1 . 0 0 \pm 7 . 8 8}}$ & $\underline{\mathbf{3 2 . 0 0 \pm 7 . 4 6}}$ \\
P. notabilis & AS Pfaffenbronn & $49.00 \pm 7.88$ & $46.00 \pm 9.30$ & $40.00 \pm 7.11$ & $\underline{\mathbf{3 0 . 0 0 \pm 8 . 2 7}}$ \\
P. notabilis & NS Pechelbronn & $37.00 \pm 9.87$ & $\underline{\mathbf{3 0 . 0 0 \pm 7 . 3 3}}$ & $\underline{\mathbf{2 6 . 0 0 \pm 8 . 9 6}}$ & $\underline{\mathbf{2 8 . 0 0 \pm 8 . 0 0}}$ \\
P. minima & AS Brunoy & $49.00 \pm 7.47$ & $48.00 \pm 8.75$ & $\underline{\mathbf{3 2 . 0 0 \pm 8 . 1 3}}$ & $\underline{\mathbf{3 3 . 0 0 \pm 7 . 1 5}}$ \\
P. minima & AS Pfaffenbronn & $58.00 \pm 7.80$ & $53.00 \pm 8.86$ & $51.00 \pm 8.88$ & $37.00 \pm 8.62$ \\
M. florae & NS Pechelbronn & $50.00 \pm 7.75$ & $42.00 \pm 7.66$ & $\underline{\mathbf{2 0 . 0 0 \pm 6 . 9 6}}$ & $\underline{\mathbf{3 1 . 0 0 \pm 7 . 1 8}}$ \\
M. macrochaeta & AS Pfaffenbronn & $51.00 \pm 7.61$ & $51.00 \pm 9.78$ & $\underline{\mathbf{3 1 . 0 0 \pm 6 . 7 2}}$ & $\underline{\mathbf{2 9 . 0 0 \pm 5 . 5 2}}$ \\
M. yosii & AS Brunoy & $52.00 \pm 8.51$ & $\underline{\mathbf{1 8 . 0 0 \pm 5 . 9 6}}$ & $\underline{\mathbf{2 8 . 0 0 \pm 8 . 8 7}}$ & $\underline{\mathbf{2 4 . 0 0 \pm 8 . 1 6}}$ \\
M. yosii & AS Pfaffenbronn & $36.00 \pm 8.03$ & $43.00 \pm 9.21$ & $\underline{\mathbf{3 2 . 0 0 \pm 8 . 0 0}}$ & $\underline{\mathbf{1 3 . 0 0 \pm 5 . 4 8}}$ \\
A. caecus & NS Brunoy & $53.00 \pm 8.62$ & $41.25 \pm 8.37$ & $\underline{\mathbf{2 5 . 5 6 \pm 7 . 6 4}}$ & $\underline{\mathbf{2 2 . 0 0 \pm 6 . 9 4}}$ \\
\hline
\end{tabular}
7 